当り $\mathrm{L} D$ 5050 $100 \mu \mathrm{g}$ 宗し, 抗 O 血清と一本の沈降 線を形成するものであり，一方 $\mathrm{P}-2$ 汃ら得られる毒菜 は, 菌体の表層画分, 恐らくは細胞壁を含む膜画分に存 在し，易熱性且つプロテアーゼで不活化される，蛋白質 を主体とする不安定な物質である。従って，腸炎ビブリ オのマウスに対する致死作用には少なくとも2 種の毒素 が関与するすのと考光られる。

なお，現在てれらの毒素，特に膜画分に局在する毒素 の精製を進めつつある。

\section{6 腸炎ビブリオのMPN算出法について}

○藤原喜久夫，土屋康子（千葉大㤫敗研）

研究目的：

腸炎ビブりオ食中毒の発症に際し，その要因の一つと して，摄取菌量の問題がある。又日常食品の検查時に， その腸炎ビブリオ污染の程度を知り, 食中毒原因食品と しての危険度を推諭するために，その中に含まれる晹炎 ビブリオの生菌数を知る必要が生ずるととがある。とて に於いて演者等は，腸炎ビブリオ生菌数算定法として， MPN 法の応用を検討したのでその概要省報告する。

\section{実験方法：}

$3 \%$ 塩化ナトリウム加BHI，コリステブィヨン，3\% 塩化ナトリウム加ペプトン水等を用いて，5本法により 最初のスクリーニングを行ない，ついでその内細菌增殖 をみたものを TTGA 培地, BTB-Teepol 寒天培地上に 接種し， $37^{\circ} \mathrm{C} 24$ 時間培養後に典型的集落発生の有無を検 べる。更に外観上晹炎ビブリオと見做されるような集落 より分離培養を試み，夫々の菌株について，形態学的， 生化学的諸性状の検查を行ない，晹炎ビブリオの規格に 合致せるものを選び出ず。最後に上記の検查の結果，晹 炎ビブリオの存在の認められた試験管の数をまとめ，そ の組合せより，MPNの表に従って腸炎ビブリオ生菌数 の値を得る。尚, 対照として, BTB-Teepol, TTGA 等の培地を用いて混勫培養を行ない，集落数の測定を試 みた。

\section{結論 :}

試験管内奏験において，腸炎ビブリオの純培養を用い てMPN 法を行った場合には，平板法による数值と比較 して，概ね一致する成績が得られたので，本法は実用に 適するるのと考觉られる。特に BTB-Teepol 寒天培地 上に扔る判定困難な集落の計数に関する問題などがな くなり，食品に応用する場合有益な方法と思われる。

\section{7 食中毒の発生要因に関する研究第 3 報病因 物質不明食中毒の疫学的解析}

務中昌已

（広大公衛）

我国の食中毒は，年間約 2000 件発生し，過去10数年来 の罹㭧率（人口10万対）は，20６0である。てれを病因 物質の面から観察すると，病因の判明したものは，細菌 性のものが大部分を占めているが，その率約 $40 \%$ ，他の $60 \%$ 前後の食中毒は，病因不明のままに終っている。演 者は，乙のような食中毒の発生事情を背景として，特に 病因物質不明の食中瑇について，広島県の過去10年間に 発生した全 365 例の食中毒事件を疫学的飞解析し，若干 の知見を得たので報告する。

1. 病因物質不明の食中籍と細菌性食中毒との季節別発 生率はよく類似している。

2. 原因食品之病因物質之の関係をみると，病因物質不 明のもの々細菌性のものが，魚介類に集積し，又各食品 別発生頻度も両者が，ほぼ同じ割合にある。

3. 病因物質と給食方法との関係は，病因物質不明のも のは，細菌性のものと同様に各給食方法別に差がなく， しかも類似した頻度で発生している。

4. 病因物質と潜代時間との関係は，病因物質不明のも のは, 平均潜伏時間16時間で, 感染型のものと類似し, 食品別に比校すると，折詰類を含む魚介類によって起て ったものとよく類似する。

5. 病因物質不明のものの平均発病率を, 原因食品別飞 みると，魚介類，甲款類，折詰類们高く，平均 $40 \%$ 前後 である。

6. 病因物質不明のものは，特に潜伏時間が $8 \sim 12$ 侍間 以上のもので惊，下㾥，腹痛が主要症状で，その時間が 長くなれば出現率が高くなり，逆に短くなれば嵒吐を主 要症状とするようになる。すなわち，病因物質不明で， 潜伏時間 $8 \sim 12$ 時間以上の食中毒は，その大部分が細菌 性，とく江感染型を嶷わせる。

7. 平山法による曝譽時点の推定から得た原因食を，そ の塩分含有度（調理科学的倠定）から推定すると，そ の大部分が晹炎ビブリオを疑わせる。

\section{自由課題}

0808

Brevibacterium の食品衛生上の意義につ いて（特に腐敗作用との関連）

楖沢文德

（医䨑大農研） ○植田早苗

（医宷大農研，女子栄羔大食品衛生） 